\title{
Gastrointestinal helminth community of loggerhead sea turtle Caretta caretta in the Adriatic Sea
}

\author{
Romana Gračan $^{1}$, Moira Buršić ${ }^{2}$, Ivona Mladineo ${ }^{3}$, Mladen Kučinić ${ }^{1}$, \\ Bojan Lazar ${ }^{1,4,5, *}$, Gordana Lacković ${ }^{1}$ \\ ${ }^{1}$ Division of Biology, Faculty of Science, University of Zagreb, 10000 Zagreb, Croatia \\ ${ }^{2}$ Center for Marine Research, Ruđer Bošković Institute, 52210 Rovinj, Croatia \\ ${ }^{3}$ Institute of Oceanography and Fisheries, 21000 Split, Croatia \\ ${ }^{4}$ Institute for Biodiversity Studies, Science and Research Centre, University of Primorska, Garibaldijeva 1, 6000 Koper, \\ Slovenia \\ ${ }^{5}$ Department of Biodiversity, Faculty of Mathematics, Natural Sciences and Information Technologies, \\ University of Primorska, Glagoljaška 8, 6000 Koper, Slovenia
}

\begin{abstract}
We analysed the intestinal helminth community of 70 loggerhead sea turtles Caretta caretta with a curved carapace length ranging from 25 to $85.4 \mathrm{~cm}$, recovered dead in neritic foraging habitats in the Adriatic Sea in 1995 to 2004. The overall prevalence of infection was high $(70.0 \%)$, with a mean abundance of 36.8 helminth parasites per turtle. Helminth fauna comprised 5 trematodes (Calycodes anthos, Enodiotrema megachondrus, Orchidasma amphiorchis, Pachypsolus irroratus, Rhytidodes gelatinosus) and 3 nematodes (Sulcascaris sulcata, Anisakis spp., Hysterothylacium sp.), with 6 taxa specific for marine turtles. In terms of infection intensity and parasite abundance, $O$. amphiorchis was the dominant species (mean intensity: 49.8 ; mean abundance: 12.8), followed by $R$. gelatinosus (30.5 and 8.3, respectively) and P. irroratus (23.5 and 7.0, respectively), while larval Anisakis spp. exhibited the highest prevalence (34.3\%). The intensity of helminth infection ranged from 1 to 302 (mean: 52.6 \pm 69.1) and was not correlated with the size of turtles; this relationship held for all species, except $R$. gelatinosus $\left(\mathrm{r}_{\mathrm{S}}=0.556, \mathrm{p}<0.05\right)$. In comparison to other marine habitats, the helminth community of Adriatic loggerheads is characterised by higher species diversity (Shannon-Wiener $H^{\prime}=1.58$ ) and evenness $(E=0.76)$, and lower dominance values (Berger-Parker $d=0.35$ ), which can be attributed to the life history and feeding ecology of sea turtles in recruited neritic grounds and the diversity of their benthic prey.
\end{abstract}

KEY WORDS: Helminth parasites $\cdot$ Sea turtles $\cdot$ Trematodes $\cdot$ Nematodes $\cdot$ Diversity $\cdot$ Population health $\cdot$ Mediterranean

\section{INTRODUCTION}

The loggerhead sea turtle Caretta caretta (Linnaeus, 1758) is an endangered, large, long-lived marine vertebrate with a worldwide distribution (IUCN 2009). This migratory species has a complex and plastic life history (Hawkes et al. 2006, McClellan \&
Read 2007, Casale et al. 2008) characterised by 2 major ecological stages. During early development, loggerheads undergo an obligate epipelagic oceanic stage, when they feed on gelatinous pelagic animals. As they grow, they gradually shift to shallow neritic habitats and concentrate their diet on a variety of benthic prey (Bjorndal 1997, Bolten 2003, Casale et 
al. 2008, Lazar et al. 2011a). Due to this highly opportunistic feeding strategy (Bjorndal 1997), coupled with a site fidelity for neritic foraging habitats (Lazar et al. 2004, Broderick et al. 2007, Casale et al. 2007) and long lifespan (Heppell et al. 2003), loggerheads are susceptible to infection with numerous trematodes and nematodes (Dodd 1988, George 1997) transmitted via intermediate hosts such as invertebrates and fish (Esch et al. 2002).

Interactions between the population biology of host and helminth parasites are of fundamental importance to the population dynamics of both the parasite and the infected host population (Anderson \& May 1978). Generally, parasites that kill their hosts are less likely to be transmitted to other hosts and will remain at low prevalence, while parasites that have little effect on host mortality and demography will usually be more prevalent. Gastrointestinal helminths often exploit the food resources in the host's digestive tract, usually producing a limited immune response and little pathological impact. However, large numbers of parasites may reduce food intake and nutrient absorption, and induce nutritional stress of the host (Petkevičius 2007), thus affecting an individual's health, growth and reproductive output (Anderson \& May 1978).

The shallow neritic zone of the Adriatic Sea, characterised by high macrofaunal density dominated by sedentary invertebrates (Vatova 1949, Zavodnik \& Vidaković 1987, McKinney 2007), represents one of the largest and most important neritic feeding grounds for loggerhead sea turtles in the Mediterranean (Margaritoulis et al. 2003, Lazar et al. 2004, 2011a, Zbinden et al. 2008). The composition of helminth fauna in loggerheads from the western Adriatic shows a wide range of helminth prevalence ( 27.7 to $78.6 \%$ ), likely attributable to small sample sizes ( $\mathrm{n}=14$ to 18 ) in the studies done so far (Manfredi et al. 1998, Piccolo \& Manfredi 2001, Scaravelli et al. 2005).

Due to the key role of Adriatic foraging habitats in the life history of Mediterranean loggerhead turtles and the possible effects of parasites on the demography of this endangered species, we quantitatively analysed the helminth community structure in the resident loggerhead population. We reviewed the preliminary data of Kučinić et al. (2008) for the eastern Adriatic and included them in the present study. We compared the component community structure of helminths in Adriatic loggerheads with those in other regions in the Mediterranean and in the adjacent area of the north-eastern Atlantic and analysed ecological factors which may determine community composition of gastrointestinal helminths in this sea turtle species.

\section{MATERIALS AND METHODS}

\section{Sampling and species identification}

Between 1995 and 2004, we collected 70 loggerhead sea turtles, with a mean notch-tip curved carapace length (CCL) of $45.0 \pm 13.6 \mathrm{~cm}$ (CCL range: 25.0 to $85.4 \mathrm{~cm}$ ). Since Caretta caretta is an endangered species, sampling of endoparasites was only conducted on turtles found dead following incidental capture by fisheries ( $\mathrm{n}=55,78.6 \%$ ) or dead stranded $(\mathrm{n}=12,17.1 \%)$ in the eastern Adriatic Sea (Croatia and Slovenia; Fig. 1). In the case of 3 turtles, the recovery method was unknown. Most of the loggerheads were recovered in the northern Adriatic ( $\mathrm{n}=$ $64,91.4 \%)$, while 6 carcasses $(8.6 \%)$ were found in its central waters.

We performed general necropsies and isolated the digestive tracts (oesophagus, stomach and intestines). The contents were rinsed in clear water through a $1 \mathrm{~mm}$ mesh sieve and fixed in $4 \%$ buffered formaldehyde. We determined the sex of turtles by visual examination of gonads and accessory ducts during necropsies (Wyneken 2001). Out of 70 loggerheads, we identified 37 females and 25 males, while sex determination was impossible for 8 turtles due to tissue decomposition.

Parasites were isolated from the gut contents under a stereomicroscope and fixed in $70 \%$ ethanol. Trematodes were prepared for detailed morphological examination by staining in Semichon's acetocarmine, dehydration through an alcohol series,

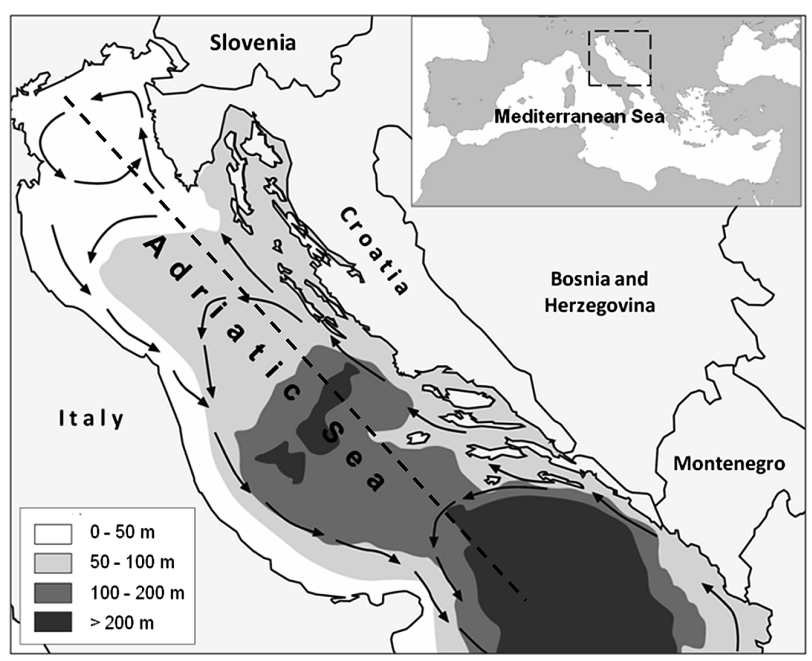

Fig. 1. Study area of the Adriatic Sea showing seafloor depth, direction of main surface currents (arrows) and division into the eastern and the western Adriatic basin (dotted line) 
clearing in toluene and mounting in Canada balsam (Lasee \& True 2004). Nematodes were examined under light microscopy at $20 \times$ and $100 \times$ magnifications, after preparation in glycerine jelly (Lasee \& True 2004). Identification of parasites was carried out following Euzet et al. (1972), Blair \& Limpus (1982), Manfredi et al. (1998), Bray (2005) and Blair (2005a,b).

\section{Quantitative descriptors of parasite infection and statistical analysis}

Parasite population structure was quantified through prevalence, mean intensity and mean abundance of each species (Margolis et al. 1982, Bush et al. 1997), calculated in the Quantitative Parasitology Program (QP 3.0; Reiczigel \& Rózsa 2005). The $95 \%$ confidence intervals of prevalence were calculated by Sterne's exact method, while for the mean intensity and mean abundance, we applied bootstrapping with 2000 bootstrap replications (Reiczigel \& Rózsa 2005). The degree of aggregation of parasites was expressed as the ratio of the variance to the mean.

We classified identified helminths either as specialists with a limited range of hosts, or as generalists exploiting more host species (Santoro et al. 2010a and references therein). In order to investigate the extent of infections in examined turtles, we arbitrarily divided animals into 2 categories based on the number of isolated parasites: turtles with light infection $(<100$ parasite specimens per turtle) and those with heavy infection $(\geq 100$ parasite specimens per turtle).

Differences in infection levels between sexes, seasons (warm season: May to October; cold season: November to April) and life stages of turtles were tested by permutational multivariate analysis of variance (PERMANOVA; Anderson 2005). For this, loggerheads were split into 2 ontogenetic groups: small juveniles (CCL $<40 \mathrm{~cm} ; \mathrm{n}=30$ ) undergoing the transitional oceanic-neritic life stage (Žiža et al. 2003, Lazar et al. 2008, Lazar \& Žiža 2010), and neritic individuals (CCL $>40 \mathrm{~cm} ; \mathrm{n}=40$ ) which predominantly feed on the sea floor (Lazar 2009, Lazar et al. 2011a). However, because some factors did not bear a sufficient number of variables (e.g. particular season or life stages, where only 5 adults were sampled versus 65 juveniles), a 1-way design was applied to square root-transformed data and Euclidian distance to assess the combined effects of tested variables on parasite abundances. Influence of body size (CCL) on the abundance and the prevalence of parasites was analysed by Spearman's rank correlation (Zar 1999). Statistical analyses were carried out with SPSS 17.0 (SPSS Inc.) and significance was assumed for values of $\mathrm{p}<0.05$.

\section{Descriptors of parasite communities}

We described the parasite infracommunity within a single host, and the component community within the host population (Bush et al. 1997, Poulin 1997) by:

(1) species richness $(S)$, defined as the total number of helminth species;

(2) the Berger-Parker dominance index $\left(d=N_{\max } /\right.$ $N$, where $N_{\max }$ is the number of individuals of the most abundant species, and $N$ is the total number of individuals);

(3) the Shannon-Wiener index $\left(H^{\prime}=-\Sigma p_{i} \ln p_{i}\right.$, where $p_{i}$ is the proportion of individuals in the $i$ th species); and

(4) Pielou's evenness index $(E)$, using species richness $(S)\left(E=H^{\prime} / \log (S)\right)$.

Formulas were calculated as described by Magurran (1988) using Primer Version 5 (Primer-E, Plymouth).

Furthermore, we compared the patterns of component community structure of helminths in loggerhead turtles from our study to those in other marine habitats in the Mediterranean and adjunct area of the Atlantic Ocean using the diversity indices described above (Shannon-Wiener index, Pielou's evenness index and Berger-Parker dominance index). As the calculation of indices requires comparable sample sizes (Wolda 1981), this was only done for 2 regions, western Mediterranean (Balearic Islands; $\mathrm{n}=54$; Aznar et al. 1998) and north-eastern Atlantic (Madeira Archipelago; $\mathrm{n}=57$; Valente et al. 2009), for which all the metadata for indices calculation were available.

\section{RESULTS}

The overall prevalence of helminth infection was $70.0 \%$ with 49 infected turtles. Parasitic communities comprised 8 helminth taxa: 5 digenetic trematodes and 3 nematodes (Table 1). We collected 2577 helminth specimens in total, with digenetic trematodes being dominant $(71.4 \%$ of total helminth abundance). The mean intensity of infection was 52.6 helminths per host, while the observed mean abundance was 36.8 parasites per turtle. As to the host specificity, helminth fauna was composed of 6 taxa exclusive to marine turtles and 2 nematodes that 
Table 1. Caretta caretta. Infection parameters of gastrointestinal helminth parasites in loggerhead sea turtles (n = 70) from the Adriatic Sea (CI: confidence interval; s: specialist for sea turtles; g: generalist)

\begin{tabular}{|c|c|c|c|c|c|c|c|}
\hline Taxon/Species & $\begin{array}{l}\text { No. of } \\
\text { infected } \\
\text { turtles }\end{array}$ & $\begin{array}{c}\text { Prevalence } \\
(95 \% \text { CI }) \\
(\%)\end{array}$ & $\begin{array}{c}\text { Mean } \\
\text { intensity } \\
(95 \% \text { CI) }\end{array}$ & $\begin{array}{c}\text { Mean } \\
\text { abundance } \\
(95 \% \mathrm{CI})\end{array}$ & $\begin{array}{l}\text { Variance-to- } \\
\text { mean ratio }\end{array}$ & $\begin{array}{l}\text { Specificity } \\
\text { to host }\end{array}$ & $\begin{array}{c}\text { No. of } \\
\text { parasites } \\
\text { detected }\end{array}$ \\
\hline \multicolumn{8}{|l|}{ Trematoda } \\
\hline $\begin{array}{l}\text { Calycodes anthos } \\
\text { (Braun, 1899) }\end{array}$ & 2 & $2.9(0.8-8.6)$ & $8.5(2.0-8.5)$ & $0.2(0.0-1.0)$ & 13.42 & $\mathrm{~s}$ & 17 \\
\hline $\begin{array}{l}\text { Enodiotrema megachondrus } \\
\text { (Looss, 1901) }\end{array}$ & $S$ & $4.3(1.2-11.9)$ & $11.3(11.0-11.7)$ & $0.5(0.0-1.1)$ & 11.02 & $\mathrm{~s}$ & 34 \\
\hline $\begin{array}{l}\text { Orchidasma amphiorchis } \\
\text { (Braun, 1899) }\end{array}$ & 18 & $25.7(16.3-37.1)$ & $49.8(27.6-84.3)$ & $12.8(6.4-25.4)$ & 108.87 & $\mathrm{~s}$ & 897 \\
\hline $\begin{array}{l}\text { Pachypsolus irroratus } \\
\text { (Rudolphi, 1819) }\end{array}$ & 21 & $30.0(20.0-42.1)$ & $23.5(12.4-49.4)$ & $7.0(3.4-15.7)$ & 77.55 & $\mathrm{~s}$ & 493 \\
\hline $\begin{array}{l}\text { Rhytidodes gelatinosus } \\
\text { (Rudolphi, 1819) }\end{array}$ & 19 & $27.1(17.7-38.6)$ & $30.5(13.8-79.1)$ & $8.3(3.2-23.4)$ & 163.57 & $\mathrm{~s}$ & 579 \\
\hline Trematoda sp. & 1 & & & & & & 2 \\
\hline \multicolumn{8}{|l|}{ Nematoda } \\
\hline Anisakis spp. & 24 & $34.3(24.0-46.4)$ & $15.3(3.9-55.5)$ & $5.2(1.4-20.6)$ & 174.75 & g & 366 \\
\hline Hysterothylacium sp. & 2 & $2.9(0.5-9.8)$ & $1.5(1.0-1.5)$ & $0.04(0.0-0.1)$ & 1.65 & g & 3 \\
\hline $\begin{array}{l}\text { Sulcascaris sulcata } \\
\text { (Rudolphi, 1918) }\end{array}$ & 14 & $20.0(11.9-31.3)$ & $13.3(5.8-34.6)$ & $2.7(1.0-8.0)$ & 58.54 & $\mathrm{~s}$ & 186 \\
\hline
\end{tabular}

occur in various hosts (Table 1). With the exception of larval-stage Anisakis spp., the parasites were only recorded in adult forms. The trematode Orchidasma amphiorchis was the most abundant species, with 897 individuals recorded in 18 turtles. If prevalence is considered, the dominant parasite was Anisakis spp., present in 24 infected turtles (prevalence: $34.3 \%$ ), followed by Pachypsolus irroratus (prevalence: $30.0 \%$ ). Our finding of genus Hysterothylacium is the first record of this parasite in loggerhead sea turtles. Two adult trematode specimens were damaged during isolation and could be identified only as Trematoda sp.

Since the variance-to-mean ratio of parasites per host was greater than 1 for all taxa, the endoparasitic community presented a distinctive overdispersed pattern of distribution, with Anisakis spp. and Rhytidodes gelatinosus displaying highly aggregated distributions (Table 1). Most of the infected turtles exhibited light infections $(81.6 \%)$, with a mean of $15.9 \pm$ 18.2 parasites per individual turtle, while 9 loggerheads $(18.4 \%)$ were heavily infected (mean: $178.4 \pm$ 73.1). The highest number of parasites was found in a loggerhead turtle of $63.0 \mathrm{~cm} \mathrm{CCL}$, which contained 302 specimens of $R$. gelatinosus. Turtles exhibiting heavy infections were infected with either $1(n=5)$ or 2 parasite species $(n=4)$. In the cases of heavy infection with 2 parasite species, 1 species was dominant with 75 to $90 \%$ abundance. The dominant species involved in multiple heavy infections were Pachypsolus irroratus, Orchidasma amphiorchis and Anisakis spp.
Helminth infections were present throughout all size classes of turtles analysed in our study, ranging from $25.0 \%$ in adults ( $>70 \mathrm{~cm} \mathrm{CCL}$ ) to $84.0 \%$ in small juveniles with 30 to $40 \mathrm{~cm} \mathrm{CCL} \mathrm{(Fig.} \mathrm{2).} \mathrm{The} \mathrm{prevalences} \mathrm{of}$ the 3 most abundant species (Orchidasma amphiorchis, Rhytidodes gelatinosus and Pachypsolus irroratus) were not evenly distributed among host size classes, with $O$. amphiorchis showing a negative correlation with increasing host size $\left(\mathrm{r}_{\mathrm{S}}=-0.943, \mathrm{p}<0.01\right.$; Fig. 3). Body size (CCL) and abundance of parasites was only significantly correlated for $R$. gelatinosus $\left(\mathrm{r}_{\mathrm{S}}=\right.$ $0.556, \mathrm{p}<0.05)$. There was a combined effect of life stage and sex $(p=0.044)$ on helminth abundance in individual turtles, with small juvenile males harbour-

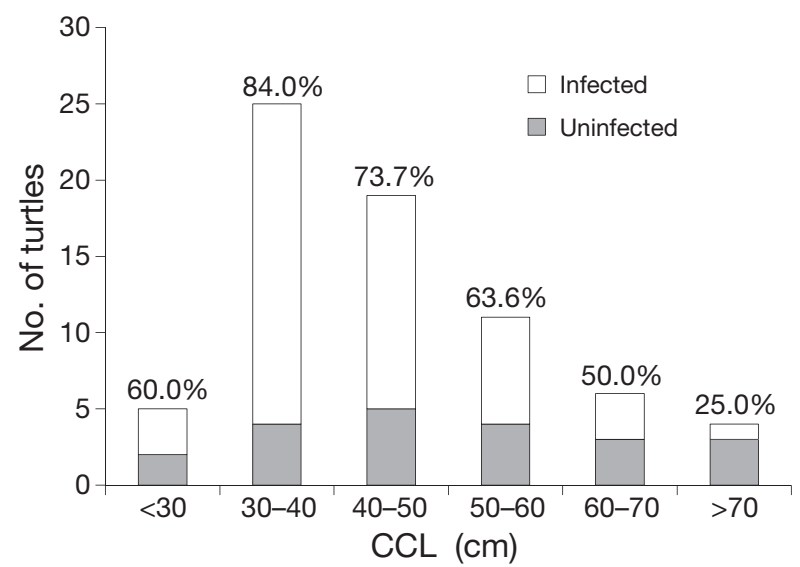

Fig. 2. Caretta caretta. Distribution of infected and uninfected loggerhead sea turtles against curved carapace length (CCL), with infection prevalences (\%) 
ing higher parasite abundances than small juvenile females (CCL < $40 \mathrm{~cm}$ ). No such discrepancy between sexes was observed in neritic-stage loggerheads.

The community structure of helminth parasites revealed a high species diversity (Shannon-Wiener $H^{\prime}=1.58$ ) and low dominance values (Berger-Parker $d=0.35$; Table 2). While species richness ranged from 1 to 5 in individual hosts, loggerheads were most frequently infected with only $1(36.7 \%)$ or 2 species $(30.6 \%)$. Parasite diversity was highest in 2 turtles $(\mathrm{CCL}=36.6$ and $58.6 \mathrm{~cm}$ ) where we detected multiple infections with 5 helminth species, represented by a relatively small number of specimens (mean number of specimens per parasite species: 5.8 \pm 4.4 and $8.2 \pm 9.7$, respectively).

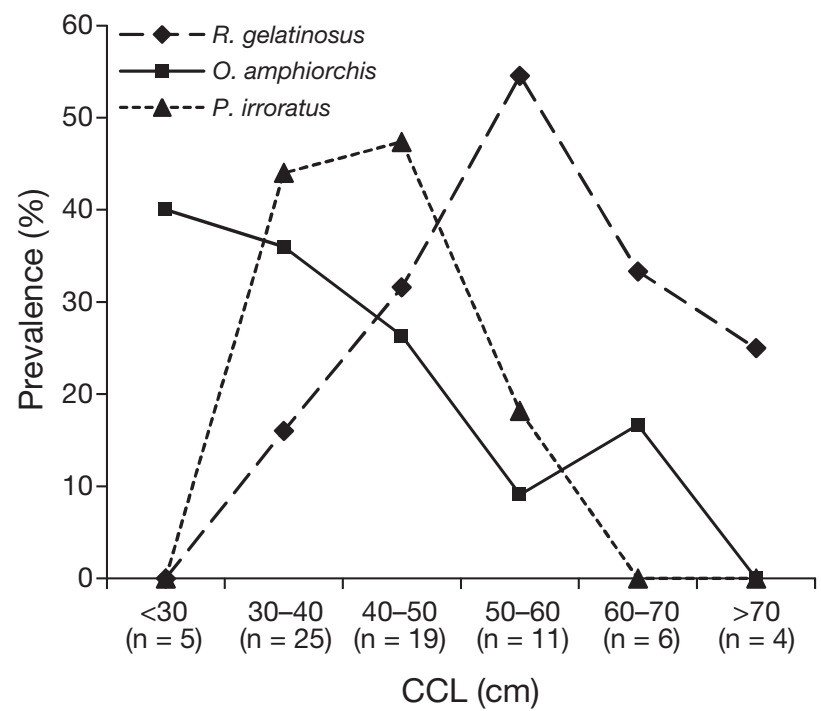

Fig. 3. Caretta caretta. Infection prevalence (\%) of the 3 most dominant helminth parasites (Rhytidodes gelatinosus, Orchidasma amphiorchis, Pachypsolus irroratus) against loggerhead sea turtle curved carapace length (CCL)
The helminth communities reported from loggerhead turtles in different regions are summarised in Table 2. In comparison to examined loggerhead turtles from the western Mediterranean (Aznar et al. 1998), or the north-eastern Atlantic (Valente et al. 2009), the helminth community in the Adriatic Sea loggerhead turtles exhibited higher diversity $\left(H^{\prime}=\right.$ 1.58), with Orchidasma amphiorchis as the dominant species. Diversity and evenness of parasite infracommunities were evidently lower in the western Mediterranean $\left(H^{\prime}=0.29\right)$ and northeast Atlantic $\left(H^{\prime}=\right.$ 0.78), with faunal composition characterised by a strong dominance of Enodiotrema megachondrus.

\section{DISCUSSION}

\section{Composition and aggregation of helminth communities}

The patterns of gastrointestinal helminth communities in wildlife populations are mostly influenced by host ranging patterns, host population density, intraspecific and interspecific contact rates, and diet (Hudson et al. 2002). Loggerhead sea turtles are large ectoterms which travel great distances and consume a wide range of prey species. As a consequence of phylogenetic barriers between sea turtles and other marine hosts, and since the loggerhead is the only abundant sea turtle species in the Mediterranean (Margaritoulis et al. 2003), helminth infracommunities exhibit a predictable composition mainly dominated by digenetic trematodes and nematodes (Aznar et al. 1998).

Although all recorded trematodes had already been identified as parasites of loggerhead sea turtles (Santoro et al. 2010a), details of the distribution of

Table 2. Caretta caretta. Comparison of helminth community structure of loggerhead sea turtles from 3 geographic regions. Data are given as available from the literature, or calculated from the source data. CCL = curved carapace length $(\mathrm{cm})$; P: prevalence; $S$ : species richness; $H^{\prime}$ : Shannon-Wiener diversity index; E: Pielou's evenness index; $d$ : Berger-Parker dominance index

\begin{tabular}{|c|c|c|c|c|c|c|c|c|c|c|}
\hline \multirow[t]{2}{*}{ Locality } & \multicolumn{2}{|c|}{ Turtles -} & \multirow[b]{2}{*}{$\mathrm{P}(\%)$} & \multirow[b]{2}{*}{$\mathrm{n}$} & \multirow[b]{2}{*}{$S$} & \multirow[b]{2}{*}{$H^{\prime}$} & \multirow[b]{2}{*}{$E$} & \multicolumn{2}{|c|}{ Helminths } & \multirow[b]{2}{*}{ Most prevalent } \\
\hline & $\mathrm{n}$ & CCL range & & & & & & $d$ & Dominant & \\
\hline $\begin{array}{l}\text { Adriatic Sea }{ }^{\mathrm{a}} \\
\text { (Slovenia and Croatia) }\end{array}$ & 70 & $25-85$ & 70 & 2577 & 8 & 1.58 & 0.76 & 0.35 & $\begin{array}{l}\text { Orchidasma } \\
\text { amphiorchis }\end{array}$ & Anisakis spp. \\
\hline $\begin{array}{l}\text { W Mediterranean }{ }^{\mathrm{b}} \\
\text { (Balearic Islands, Spain) }\end{array}$ & 54 & $34-69$ & 100 & 7098 & 5 & 0.29 & 0.18 & 0.93 & $\begin{array}{l}\text { Enodiotrema } \\
\text { megachondrus }\end{array}$ & $\begin{array}{l}\text { Enodiotrema } \\
\text { megachondrus }\end{array}$ \\
\hline $\begin{array}{l}\text { NE Atlantic }{ }^{\mathrm{C}} \\
\text { (Madeira, Portugal) }\end{array}$ & 57 & $15-61$ & 45.6 & 143 & 8 & 0.78 & 0.38 & 0.76 & $\begin{array}{l}\text { Enodiotrema } \\
\text { megachondrus }\end{array}$ & Anisakis spp. \\
\hline
\end{tabular}




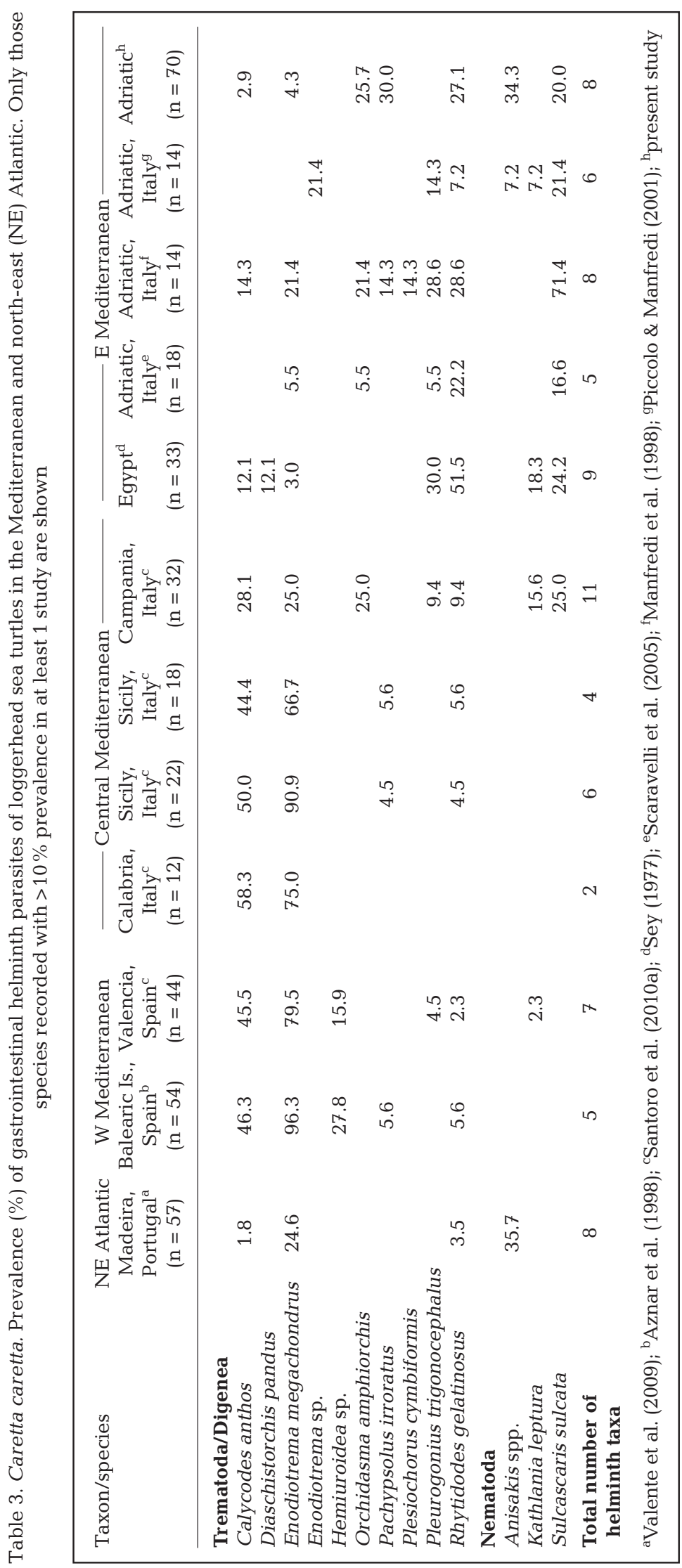

developmental stages and life cycles in intermediate/paratenic and definitive hosts are largely unknown. Life cycles with pelagic intermediate hosts have only been proposed for Enodiotrema megachondrus and Calycodes anthos (Santoro et al. 2010a). In contrast to trematodes specific to marine turtles, 2 of the 3 identified nematodes are generalists (Anisakis spp. and Hysterothylacium sp.), infecting a variety of hosts. Anisakis spp. was the most prevalent parasite in the present study. It was only recorded in larval forms, which made species identification based upon morphological characteristics impossible. This genus contains a complex of sibling species which may be differentiated only by genetic analysis. Mitochondrial DNA sequencing of Anisakis spp. in loggerheads from the central and western Mediterranean (Santoro et al. 2010a) and the distribution of dominant species within this complex in the Mediterranean (Mattiucci \& Nascetti 2006, Santoro et al. 2010b) and the Adriatic Sea (Petri et al. 2011) suggest that larvae from the present study most likely belong to $A$. pegreffii.

Larval-stage Anisakis are found in crustaceans, squid and fish, while adults parasitize the gastrointestinal tracts of marine mammals (Mattiucci \& Nascetti 2006, 2008). Sea turtles are considered as accidental paratenic hosts harbouring larvae with no possibility for further development, and therefore represent ecological dead end hosts (Santoro et al. 2010a,b). With the exception of our study and that of Valente et al. (2009) in the north-eastern Atlantic, only low prevalences of Anisakis spp. have been recorded in loggerhead turtles $(<10 \%$; Table 3 and references therein). According to Valente et al. (2009), a high prevalence of Anisakis spp. larvae in loggerheads may be explained by a high abundance of their definitive hosts - marine mammals - in the area. Recent studies have shown high diversity and abundance of cetaceans in the Adriatic Sea, especially of bottlenose dolphins (Bearzi et al. 2009, Fortuna et al. 2010), which may explain the generally high abundance of Anisakis spp. in the region (Mladineo 2004, Mladineo et al. 2011) and, consequently, the high infection rates in loggerheads.

The low prevalence and low abundance of $\mathrm{Hys}$ terothylacium sp. found in our study $(2.9 \%$ and $0.04 \%$, respectively), and the complete absence of this genus in loggerheads from other localities, might indicate accidental infection. Infection with this parasite could occur through the inges- 
tion of fish discarded from fishing vessels, since the adult stages of the species live in teleosts (Bruce et al. 1994, Torres et al. 1998).

The nematode Sulcascaris sulcata is a frequently recorded parasite of loggerhead sea turtles (Baylis 1923, Sey 1977, Sprent 1977, Manfredi et al. 1998, Piccolo \& Manfredi 2001, Scaravelli et al. 2005, Santoro et al. 2010a). It has a life cycle modulated between benthic gastropods and bivalves as intermediate hosts and marine turtles as definitive hosts (Lichtenfels et al. 1978, Berry \& Cannon 1981). As slow moving and sessile intermediate hosts cannot contribute to the large-scale dispersal of parasites (Thieltges et al. 2009), the distribution of S. sulcata is restricted to shallow coastal regions where these benthic molluscs are abundant. In the Mediterranean, the occurrence of $S$. sulcata in loggerheads seems to be limited to its eastern basin, while the species is absent in the western Mediterranean and north-eastern Atlantic populations, as well as in those from the larger part of the central Mediterranean (Table 3 and references therein).

A similar distribution pattern seems to be shared by Rhytidodes gelatinosus, which exhibits a low prevalence in loggerheads throughout the Mediterranean and north-eastern Atlantic, but has been frequently found in shallow regions along the northern African shelf (Egypt) and in the Adriatic Sea (Table 3).

\section{Host ontogeny and helminth infections}

The ontogeny and life history of a host have major influence on the species richness and abundance of its parasite communities (Santoro et al. 2010a). In loggerhead turtles, the duration of the developmental stages and the size at recruitment to the neritic zone differ between populations (Bjorndal et al. 2000, Limpus \& Limpus 2003). Loggerheads in the Adriatic Sea, for example, exhibit an early ontogenetic habitat shift (CCL $\geq 30 \mathrm{~cm}$ ), when they start to feed primarily upon benthic invertebrates, such as benthic molluscs, cnidarians and crustaceans (Žiža et al. 2003, Lazar et al. 2008, 2011a). These small juveniles that occupy neritic habitats in the northern Adriatic still carry parasite loads from their oceanic habitats, but at the same time they start to be exposed to parasites from the benthic food webs. Our finding of Enodiotrema megachondrus, a species with pelagic intermediate hosts, only in small juvenile loggerheads (CCL ranging from 25.0 to $36.6 \mathrm{~cm} ; \mathrm{n}=3$ ) supports this assumption. Moreover, the highest prevalence of helminth parasites was recorded in turtles with a CCL ranging from 30 to $40 \mathrm{~cm}(84.0 \%$; Fig. 2), which were undergoing the transitional period from oceanic to neritic habitats. This suggests that the transitional oceanic-neritic period in the loggerhead's life history is associated with an elevated risk of helminth acquisition.

The helminth community structure of loggerhead turtles from the western Mediterranean and the north-eastern Atlantic are characterised by high Berger-Parker dominance indices for Enodiotrema megachondrus (0.93 and 0.76 respectively; Table 2). In Balearic waters, E. megachondrus was present in $96.3 \%$ of hosts (Aznar et al. 1998), while loggerheads from the Madeira Archipelago exhibited low prevalence $(24.6 \%)$ of infections due to oligotrophic conditions in the vast oceanic zone, where intermediate hosts are dispersed and in low population densities (Valente et al. 2009). Although this sea turtle species may temporarily switch to bottom feeding in the vicinity of seamounts or around oceanic islands (Bolten 2003), both marine regions primarily constitute oceanic developmental habitats. For example, dietary analyses have emphasised pelagic tunicates and discarded fish from bycatch as the major prey of loggerheads in the western Mediterranean (Balearic Islands; Tomás et al. 2001). Similarly, studies in the north-eastern Atlantic (Azores) have shown an epipelagic behavioural pattern of juveniles, with $75 \%$ of the time spent in the top $5 \mathrm{~m}$ of the water column and $80 \%$ of dives to depths of only 2 to $5 \mathrm{~m}$ (Bolten 2003). This feeding strategy is reflected in the helminth parasite community, which is dominated by species with pelagic life cycles. In the Adriatic, parasites such as E. megachondrus and Calycodes anthos were present in loggerheads at low prevalence and were only found in small juvenile turtles. Our study area, however, included neritic feeding habitats (Lazar et al. 2004, 2011a), resulting in a markedly different composition of the helminth parasite community, which was characterised by a lower dominance value (Berger-Parker $d=0.35$ ), a higher diversity (Shannon-Wiener $H^{\prime}=1.58$ ) and Orchidasma amphiorchis as the dominant species. Established differences between helminth communities of loggerheads in the oceanic and neritic zones confirm the importance of host ontogeny and diet in the structuring of gastrointestinal parasitic communities (Santoro et al. 2010a).

Most of the turtles analysed in the present study $(>90 \%)$ were recovered from the shallow waters of 
the northern Adriatic (<100 m depth; Fig. 1). In these waters, all turtles, regardless of size and sex, access the same food resources throughout the year. This should result in an even susceptibility to parasite infections and a lack of differences in infracommunity structure between sexes and seasons, as observed in other marine habitats of loggerheads in the Mediterranean (Santoro et al. 2010a). The sex-related differences which we found in parasite abundances in small juveniles $(p<0.05)$ can plausibly be attributed to the statistically small sample size of animals in this life stage, but might also be the result of a difference in movement patterns between oceanic males and females (Casale et al. 2002).

In conclusion, loggerhead turtles using the feeding habitats of the Adriatic Sea exhibited relatively high infection rates $(70 \%)$ with intestinal helminths. The available helminth species, combined with the specific life history and broad diet of the host, are likely the main factors shaping parasite community composition and richness. Helminth populations in the Adriatic exhibited aggregated distribution, mostly causing light infections. However, anthropogenic drivers such as fisheries interactions and pollution may alter the dynamics of parasites and host (Kennedy \& Watt 1994, Des Clers \& Wootten 1990). High fishing effort and pollution have already been identified as major threats to resident loggerhead populations (Lazar \& Tvrtković 1995, Casale et al. 2004, 2010, Storelli et al. 2007, Lazar \& Gračan 2011, Lazar et al. 2011b). The potential influence of intestinal parasites on the demographics of host populations is therefore a factor of concern, particularly for small juvenile loggerheads in the Adriatic Sea.

Acknowledgements. This study was carried out within the research project nos. 119-1193080-3171, 183-1193080-0831 and 001-0000000-3633 of the Ministry of Science, Education and Sports of Croatia, under the permit nos. 612-07/9731/67 and 531-06/1-02-2 of the Ministry of Environmental Protection and Physical Planning of Croatia, and the permit nos. 354-09-66/00, 35714-165/01 and 35701-94/2004 of the Ministry of the Environment, Spatial Planning and Energy of Slovenia. The material was transported according to the CITES import permit nos. 05/02 and 120/02, and the export permit nos. 02SI000001/EX and 02SI000147/EX. We thank our students J. Katić, S. Galetović and D. Miše for their help in laboratory analysis. We are also thankful to V. Žiža (Aquarium Piran, Slovenia) and to collaborating fishermen for their help in collecting the loggerhead sea turtles. We used the MAPTOOL program for graphics in the paper; MAPTOOL is a product of seaturtle.org (http://seaturtle .org/maptool/). The final manuscript was improved thanks to constructive comments of 2 anonymous reviewers.

\section{LITERATURE CITED}

Anderson MJ (2005) PERMANOVA: a FORTRAN computer program for permutational multivariate analysis of variance. Department of Statistics, University of Auckland

Anderson RM, May RM (1978) Regulation and stability of host-parasite population interactions. I. Regulatory processes. J Anim Ecol 47:219-247

Aznar FJ, Badillo FJ, Raga JA (1998) Gastrointestinal helminths of loggerhead turtles (Caretta caretta) from the western Mediterranean: Constraints on community structure. J Parasitol 84:474-479

Baylis HA (1923) Report on a collection of parasitic nematodes, mainly from Egypt. Part I. Ascaridae and Heterakidae. Part 11. Oxyuridae. Part 111. Camallanidae, etc. with a note on Probstmayria and an appendix on Acanthocephala. Parasitology 15:1-38

> Bearzi G, Fortuna CM, Reeves RR (2009) Ecology and conservation of common bottlenose dolphins Tursiops truncatus in the Mediterranean Sea. Mammal Rev 39: 92-123

Berry GN, Cannon LRG (1981) The life history of Sulcascaris sulcata (Nematoda: Ascaridoidea), a parasite of marine molluscs and turtles. Int J Parasitol 11:43-54

Bjorndal KA (1997) Foraging ecology and nutrition of sea turtles. In: Lutz PL, Musick JA (eds) The biology of sea turtles. CRC Press, Boca Raton, FL, p 199-231

Bjorndal KA, Bolten AB, Martins HR (2000) Somatic growth model of juvenile loggerhead sea turtles Caretta caretta: duration of pelagic stage. Mar Ecol Prog Ser 202:265-272

Blair D (2005a) Family Rhytidodidae (Odhner 1926). In: Jones A, Bray RA, Gibson DI (eds) Keys to the trematoda, Vol 2. CABI Publishing, Wallingford, p 123-125

Blair D (2005b) Family Pronocephalidae (Looss 1899). In: Jones A, Bray RA, Gibson DI (eds) Keys to the trematoda, Vol 2. CABI Publishing, Wallingford, p 361-380

Blair D, Limpus CJ (1982) Some digeneans (Platyhelminthes) parasitic in the loggerhead turtle, Caretta caretta (L.), in Australia. Aust J Zool 30:653-680

Bolten AB (2003) Variation in sea turtle life history patterns: neritic vs. oceanic developmental stages. In: Lutz PL, Musick JA, Wyneken J (eds) The biology of sea turtles, Vol 2. CRC Press, Boca Raton, FL, p 243-257

Bray RA (2005) Deep-sea parasites. In: Rohde K (ed) Marine parasites. CABI Publishing and CSIRO Publishing, Collingwood, p 366-369

Broderick AC, Coyne MS, Fuller WJ, Glen F, Godley BJ (2007) Fidelity and overwintering of sea turtles. Proc R Soc Lond B Biol Sci 274:1533-1538

> Bruce NL, Adlard RD, Cannon LRG (1994) Synoptic checklist of ascaridoid parasites (Nematoda) from fish hosts. Invertebr Taxon 8:583-674

> Bush AO, Lafferty KD, Lotz JM, Shostak AW (1997) Parasitology meets ecology on its own terms: Margolis et al. revisited. J Parasitol 83:575-583

> Casale P, Laurent L, Gerosa G, Argano R (2002) Molecular evidence of male-biased dispersal in loggerhead turtle juveniles. J Exp Mar Biol Ecol 267:139-145

> Casale P, Laurent L, De Metrio G (2004) Incidental capture of marine turtles by the Italian trawl fishery in the north Adriatic Sea. Biol Conserv 119:287-295

> Casale P, Freggi D, Basso R, Vallini C, Argano R (2007) A model of area fidelity, nomadism, and distribution patterns of loggerhead sea turtles (Caretta caretta) in the Mediterranean Sea. Mar Biol 152:1039-1049 
Casale P, Abbate G, Freggi D, Conte N, Oliverio M, Argano R (2008) Foraging ecology of loggerhead sea turtles Caretta caretta in the central Mediterranean Sea: evidence for a relaxed life history model. Mar Ecol Prog Ser 372:265-276

Casale P, Affronte M, Insaccod G, Freggi D and others (2010) Sea turtle strandings reveal high anthropogenic mortality in Italian waters. Aquat Conserv: Mar Freshw Ecosyst 20:611-620

$>$ Des Clers S, Wootten R (1990) Modelling the population dynamics of the sealworm Pseudoterranova decipiens. Neth J Sea Res 25:291-299

Dodd CK (1988) Synopsis of the biological data on loggerhead sea turtle Caretta caretta (Linnaeus 1758). US Fish Wildl Serv, Biol Rep 88

Esch GW, Barger MA, Fellis KJ (2002) The transmission of digenetic trematodes: style, elegance, complexity. Integr Comp Biol 42:304-312

Euzet L, Combes C, Triquell A (1972) Sur deux Trématodes de Caretta caretta (L.) des côtes Méditerranéennes Françaises. Vie Milleu 23:157-167

Fortuna C, Holcer D, Filidei E, Mackelworth P, Tunesi L (2010) Distribution and abundance of megafauna in the Adriatic Sea: relevance for identification of important marine areas. 3rd Int Workshop on Biodiversity in the Adriatic 'Towards a representative network of marine protected areas in the Adriatic', October 2010, Piran, Slovenia, p 11-12

George RH (1997) Health problems and disease of sea turtles. In: Lutz PL, Musick JA (eds) The biology of sea turtles. CRC Press, Boca Raton, FL, p 363-385

Hawkes LA, Broderick AC, Coyne MS, Godfrey MH and others (2006) Phenotypically linked dichotomy in sea turtle foraging requires multiple conservation approaches. Curr Biol 16:990-995

Heppell SS, Snover ML, Crowder LB (2003) Sea turtle population ecology. In: Lutz PL, Musick JA, Wyneken J (eds) The biology of sea turtles, Vol 2. CRC Press, Boca Raton, FL, p 275-306

Hudson PJ, Rizzoli A, Grenfell BT, Heesterbeek H, Dobson AP (2002) The ecology of wildlife diseases. Oxford University Press, Oxford

IUCN (2009) IUCN Red list of threatened species. Version 2009.2. Accessed 16 February 2010. www.iucnredlist.org

Kennedy CR, Watt RJ (1994) The decline and natural recovery of an unmanaged coarse fishery in relation to changes in land use and attendant eutrophication. In: Cowx IG (ed) Rehabilitation of freshwater fisheries. Blackwell Scientific, Oxford, p 366-375

Kučinić M, Lazar B, Zavodnik D, Tvrtković N (2008) Intestinal helminths of loggerhead sea turtle (Caretta caretta) from the eastern Adriatic Sea. In: Mast RB, Hutchinson BJ, Hutchinson AH (eds) Proc 24th Annu Symp Sea Turtle Biol Conserv, NOAA Tech Memo NMFS-SEFSC-567, p 99

Lasee B, True K (2004) Parasitology. In: True K (ed) National wild fish health survey procedures manual, 2nd edn. US Fish and Wildlife Service, Anderson, CA, p 1-37

Lazar B (2009) Ecology and conservation of loggerhead sea turtle Caretta caretta (Linnaeus 1758) in the eastern Adriatic Sea. PhD dissertation, University of Zagreb (in Croatian with English Abstract)

Lazar B, Gračan R (2011) Ingestion of marine debris by loggerhead sea turtles, Caretta caretta, in the Adriatic Sea. Mar Pollut Bull 62:43-47
Lazar B, Tvrtković N (1995) Marine turtles in the eastern part of the Adriatic Sea: preliminary research. Natura Croat 4:59-74

Lazar B, Žiža V (2010) Slovenia. In: Casale P, Margaritoulis D (eds) Sea turtles in the Mediterranean. IUCN, Gland, p 197-202

> Lazar B, Margaritoulis D, Tvrtković N (2004) Tag recoveries of the loggerhead sea turtle, Caretta caretta, in the eastern Adriatic Sea and implications for conservation. J Mar Biol Assoc UK 84:475-480

Lazar B, Gračan R, Zavodnik D, Tvrtković N (2008) Feeding ecology of 'pelagic' loggerhead turtles, Caretta caretta, in the northern Adriatic Sea: proof of an early ontogenetic habitat shift. In: Kalb H, Rohde AS, Gayheart K, Shanker K (eds) Proc 25th Annu Symp Sea Turtle Biol Conserv, NOAA Tech Memo NMFS-SEFSC-582, p 93

Lazar B, Gračan R, Katić J, Zavodnik D, Jaklin A, Tvrtković N (2011a) Loggerhead sea turtles (Caretta caretta) as bioturbators in neritic habitats: an insight through the analysis of benthic molluscs in the diet. Mar Ecol 32: 65-74

Lazar B, Maslov L, Herceg Romanić S, Gračan R, Krauthacker B, Holcer D, Tvrtković N (2011b) Organochlorine contaminants in loggerhead sea turtles, Caretta caretta, from eastern Adriatic Sea. Chemosphere 82:121-129

Lichtenfels JR, Bier JW, Madden PA (1978) Larval anisakid (Sulcascaris) nematodes from Atlantic mollusks with marine turtles as definitive hosts. Trans Am Microsc Soc 97:199-207

Limpus CJ, Limpus DJ (2003) Biology of the loggerhead turtle in western south Pacific Ocean foraging areas. In: Bolten AB, Witherington B (eds) Loggerhead sea turtles. Smithsonian Books, Washington, DC, p 93-113

Magurran AE (1988) Ecological diversity and its measurement. Croom-Helm, London

Manfredi MT, Piccolo G, Meotti C (1998) Parasites of Italian sea turtles. II. Loggerhead turtles (Caretta caretta [Linnaeus, 1758]). Parassitologia 40:305-308

Margaritoulis D, Argano R, Baran I, Bentivegna F and others (2003) Loggerhead turtles in the Mediterranean: present knowledge and conservation perspectives. In: Bolten A, Witherington B (eds) Ecology and conservation of loggerhead sea turtles. Smithsonian Institution Press, Washington, DC, p 175-198

> Margolis L, Esch GW, Holmes JC, Kuris AM, Schad GA (1982) The use of ecological terms in parasitology (report of an ad hoc committee of the American Society of Parasitologists). J Parasitol 68:131-133

Mattiucci S, Nascetti G (2006) Molecular systematics, phylogeny and ecology of anisakid nematodes of the genus Anisakis Dujardin, 1845: an update. Parasite 13: 99-113

> Mattiucci S, Nascetti G (2008) Advances and trends in the molecular systematics of anisakid nematodes, with implications for their evolutionary ecology and host-parasite co-evolutionary processes. Adv Parasitol 66:47-148

McClellan CM, Read AJ (2007) Complexity and variation in loggerhead sea turtle life history. Biol Lett 3:592-594

McKinney FK (2007) The northern Adriatic ecosystem: deep time in a shallow sea. Columbia University Press, New York, NY

Mladineo I (2004) Prevalence of infection, predilectional sight and morphological characteristics of Anisakis simplex (Nematoda, Anisakida) from the Adriatic Sea. Period Biol 105:389-392 
Mladineo I, Šegvić T, Petrić M (2011) Do captive conditions favor shedding of parasites in the reared Atlantic bluefin tuna (Thunnus thynnus)? Parasitol Int 60:25-33

Petkevičius S (2007) The interaction between intestinal helminth infection and host nutrition. Vet Ir Zootech 37: 53-63

Petrić M, Mladineo I, Krstulović Šifner S (2011) Insight in the short-finned squid Illex coindetii (Cephalopoda: Ommastrephidae) feeding ecology: Is there a link between helminth parasites and food composition? J Parasitol 97: 55-62

Piccolo G, Manfredi MT (2001) New reports on parasites of marine turtles stranded along the Italian coasts. In: Margaritoulis D, Demetropoulos A (eds) Proc 1st Mediterranean Conf Marine Turtles. Barcelona Convention - Bern Convention - Bonn Convention (CMS), Nicosia, Cyprus, p 207-211

Poulin R (1997) Species richness of parasite assemblages: evolution and patterns. Annu Rev Ecol Syst 28:341-358

Reiczigel J, Rózsa L (2005) Quantitative Parasitology 3.0. Budapest. Accessed 13 June 2010. www.zoologia.hu/ qp/qp.html

Santoro M, Badillo FJ, Mattiucci S, Nascetti G and others (2010a) Helminth communities of loggerhead turtles (Caretta caretta) from Central and Western Mediterranean Sea: the importance of host's ontogeny. Parasitol Int 59:367-375

Santoro M, Mattiucci S, Paoletti M, Liotta A, Degli Uberti B, Galiero G, Nascetti G (2010b) Molecular identification and pathology of Anisakis pegreffii (Nematoda:Anisakidae) infection in the Mediterranean loggerhead sea turtle (Caretta caretta). Vet Parasitol 174:65-71

Scaravelli D, Gustinelli A, Nardini G, Cucinotta G, Affronte M, Trentini M, Fioravanti ML (2005) A parasitological survey of loggerhead turtles (Caretta caretta) from the northern Adriatic Sea. In: Demetropoulos A, Türkozan O (eds) Proc 2nd Mediterranean Conf Marine Turtles. Barcelona Convention - Bern Convention - Bonn Convention (CMS), Antalya, Turkey, p 45

Sey O (1977) Examination of helminth parasites of marine turtles caught along the Egyptian coast. Acta Zool Acad Sci Hung 23:387-394

Sprent JFA (1977) Ascaridoid nematodes of amphibians and reptiles: Sulcascaris. J Helminthol 51:379-387

Editorial responsibility: Andrew Cunningham, London, UK
Storelli MM, Barone G, Marcotrigiano GO (2007) Polychlorinated biphenyls and other chlorinated organic contaminants in the tissues of Mediterranean loggerhead turtle Caretta caretta. Sci Total Environ 373:456-463

$>$ Thieltges DW, Ferguson MAD, Jones CS, Krakau M and others (2009) Distance decay of similarity among parasite communities of three marine invertebrate hosts. Oecologia 160:163-173

Tomás J, Aznar FJ, Raga JA (2001) Feeding ecology of the loggerhead turtle Caretta caretta in the western Mediterranean. J Zool 255:525-532

Torres P, Andrade P, Silva R (1998) On a new species of Hysterothylacium (Nematoda: Anisakidae) from Cauque mauleanum (Pisces: Atherinidae) by brightfield and scanning electron microscopy. Mem Inst Oswaldo Cruz 93:745-752

> Valente AL, Delgado C, Moreira C, Ferreira S, Dellinger T, Pinheiro de Carvalho MAA, Costa G (2009) Helminth component community of the loggerhead sea turtle, Caretta caretta, from Madeira Archipelago, Portugal. J Parasitol 95:249-252

Vatova A (1949) La fauna bentonica dell'alto e medio Adriatico. Nova Thalassia 1:1-110

Wolda H (1981) Similarity indices, sample size and diversity. Oecologia 50:296-302

Wyneken J (2001) The anatomy of sea turtles. US Department of Commerce Miami, NOAA Tech Memo NMFSSEFSC-470

Zar JH (1999) Biostatistical analysis, 4th edn. Prentice Hall, Upper Saddle River

Zavodnik D, Vidaković J (1987) Report on bottom fauna in two northern Adriatic areas presumed to be influenced by inputs. FAO Fish Rep 352 (Suppl):263-279

Zbinden JA, Aebischer A, Margaritoulis D, Arlettaz R (2008) Important areas at sea for adult loggerhead sea turtles in the Mediterranean Sea: satellite tracking corroborates findings from potentially biased sources. Mar Biol 153: 899-906

Žiža V, Marenčić Z, Turk R, Lipej L (2003) First data on the loggerhead turtle (Caretta caretta) in Slovenia (north Adriatic). In: Margaritoulis D, Demetropoulos A (eds) Proc 1st Mediterranean Conf Marine Turtles. Barcelona Convention-Bern Convention-Bonn Convention (CMS), Nicosia, Cyprus, p 261-264

Submitted: December 30, 2010; Accepted: May 23, 2012 Proofs received from author(s): July 18, 2012 